\title{
Analyzing Effectiveness Of Learning Management System In Present Scenario: Conceptual Background And Practical Implementation
}

\author{
Mr. Subhajit Panda \\ Assistant Librarian, Chandigarh University, Mohali, Punjab, India
}

\begin{abstract}
Coronavirus is a widespread dangerous disease in recent months, originated in China but with a great impact at the global level. As a result, the education process is choked by shut down of college \& universities and maintaining social distancing for reducing the outbreak from community transmission. The purpose of this study is to explore the effectiveness of Learning Management System (LMS) in higher education to support teaching and learning in this 'new normal' by providing a stand-alone platform for online \& distance learning. LMS is a software application for administering, documenting, tracking, reporting, automating, and delivering educational, training, or learning and development programmes; which originated directly from the concept of e-learning. With the detailed conceptual approach of LMS, the study also associates with the practical implementation of Blackboard LMS in Chandigarh University. Additionally, the study also tastes a comparative analysis between Blackboard, Canvas \& Moodle LMS.
\end{abstract}

Keywords: Blackboard, Canvas, Distance Learning, e-Learning, Learning Management System, LMS, Moodle, Online Learning,

\section{INTRODUCTION}

The outbreak of present pandemic Coronavirus [first called 2019-nCoV and officially renamed as SARS-CoV2 (the virus) and COVID-19 (the disease)] (Sarukhan, 2020) is become a global threat and has a clear negative impact on humanity, including human life and knowledge creation, as a standard of human development. People keep themselves at home to maintain social distancing for reducing the outbreak of community transmission (Panda, 2020). As a result, both the effects of education system i.e. direct $\&$ indirect effects are now a subject risk to this pandemic. It requires a new approach to the learning system, a transition from conventional to digital. The primary requirements of this transition are sufficient availability of e-content, a multitasking online learning platform and cloud storage for preservation. A Learning Management System (LMS) ensure the facility of all above-mentioned features and stimulate the efforts of institutions and educators to meet the challenges of this 'new normal' to facilitate teaching and enhance learning.

\section{LITERATURE REVIEW}

Here we discussed some prominent literature which visualizes the use \& utilization of LMS in the present era of information age to support distance learning or study from home, Rahman et al. (2019) aimed to investigate the use of LMS in teaching and learning process in higher education, specifically, identified the knowledge and benefits of using LMS as perceived by students studying education programs. Tretinjak (2018), in his paper explored how to move teaching from blackboard to the Schoology learning management system in order to help absent students learn from home. In their study de Porto Alegre Muniz \& de Moraes, (2012) focused about the usability of Learning Management Systems (LMS), specifically in the case of open source system Moodle. Iqbal \& Qureshi, (2011) identified the desired functionalities which are more essential in an LMS and are concerned ability to create student groups for group activities, availability of discussion board, announcement board and online quizzes, file sharing/transfer functionality etc. The research of Martin 
(2008) sought to investigate the utility of content delivery and how it helped students develop computer skills through an online survey using Blackboard as the LMS at a large southwestern university.

\section{OBJECTIVES OF THE STUDY}

$\checkmark \quad$ To examine about the conceptual framework of LMS.

$\checkmark \quad$ To study the essential structural requirements i.e. the four factors of LMS.

$\checkmark$ To discuss additionally about various types of LMS development options, customer types, licensing types, pricing models, and specification support types.

$\checkmark$ To encourage the use of LMS by providing its advantages, considering the viewpoint of the students and the teachers.

$\checkmark \quad$ To display detail practical implementation of Blackboard LMS in Chandigarh University.

$\checkmark \quad$ To compare basic functionality and features between Blackboard, Canvas \& Moodle LMS.

\section{SCOPE OF THE STUDY}

The study started with the detailed conceptual approach of the Learning Management System, its advantages and various functionality which can be used in distance learning in the present situation of COVID-19 outbreak. The second part of the study gives a practical approach to the implementation of Blackboard LMS in Chandigarh University for adapting online learning scenario started from August semester. Additionally, the study covers a basic comparison between Blackboard, Canvas \& Moodle LMS.

\section{LEARNING MANAGEMENT SYSTEM (LMS): CONCEPTUAL APPROACH}

\section{A. BACKGROUND STUDY}

Distance learning encountered an immense problem before the advent of the Internet and World Wide Web (WWW). At that time, offline resources, like CD ROMS \& pre-recorded sessions, as well as online resources, like satellite $\&$ closed-circuit television were used for distance learning in universities and colleges. When the Internet became popular in the 1990s, it unleashed the potential of using the Internet in education (Fuller et al., 2000). Course Management Systems (CMS) were introduced in the 1990s which later on emerged into LMS. Both the terms CMS \& LMS are synonyms. In terms of use, a CMS is more focused on the contents and delivery of the course, whereas an LMS is more focused on the learning need and achievement of a person (Simonson et al., 2019). Joomla is an example of CMS, whereas Blackboard and Canvas are examples of LMS (Joomla, 2005; Blackboard, 1997; Canvas, 2011).

\section{B. DEFINITION}

A learning management system (LMS) is a software application for the administration, documentation, tracking, reporting, and delivery of educational courses, training programs, or learning and development programs (Rahman et al. 2019). As defined by Parmley (2018), LMS is a "software that helps deliver your training material in a way that makes it easily accessible to your students. An LMS structures the content offers a central login area for students and provides an admin area for user management as well as course management." According to Naveh et al., (2010), "A LMS is a web-based system that provides an infrastructure to deliver course content, monitor participation, assess students, and facilitate communication through a number of built-in tools". Oakes (2002) explained LMS as a tool for "learner and organization focused: It's concerned with the logistics of managing learners, learning activities and the competency mapping of an organization."

\section{ESSENTIAL STRUCTURAL REQUIREMENTS}

The role of a Learning Management System varies depending on the organization's objectives, online training strategy, and desired outcomes. Accordingly, the selection of an LMS is depended upon the factors which lead to fulfilling the aim \& objectives of a particular organization - such as organizational needs and requirements, availability of appropriate technical support and LMS capabilities. Thus, the factors (figure 1) which considered most important for the selection of an LMS are organizational goals and objectives, technical support and specifications, LMS design and functionalities and pedagogical support provided by an LMS.

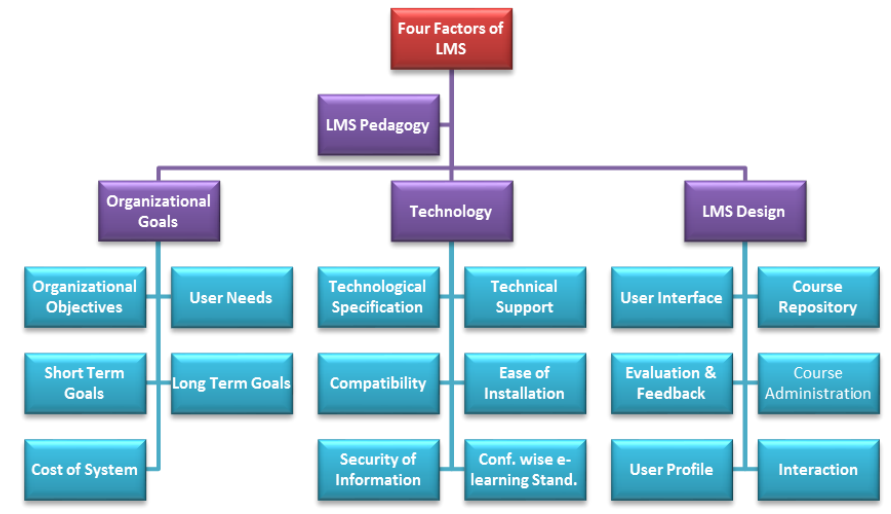

Figure 1: Four factors of LMS

$\checkmark$ ORGANIZATIONAL GOALS AND OBJECTIVES: What an LMS offers is more important than how it is being offered. Nowadays, the e-learning platforms highlight the "electronic" part more for marketing purpose and compromise with the learning part (Middleton, 2010). As a result, the main objectives of the blended learning system distract from its main goal. An organization should be clear about its need \& objective while selecting an LMS. These objectives primarily address both the short term \& long term goals of the organization. The implementation of an LMS would be a fruitful endeavour if the LMS were ideally suited to satisfy these goals 
(Ismail, 2002). In addition, the expense of LMS should also be within the budget constraints of the organization.

$\checkmark$ TECHNICAL SPECIFICATIONS AND SUPPORT: In an organization initiating of an e-learning programme will end up in disaster without continuous technical support (Selim, 2007). The LMS should be compatible with the system currently being used by the organization to ensure easy integration \& maximum productivity. Additionally, the LMS should be easy to install \& operate. For such integration, LMS involves uploading \& storing a lot of confidential information, which requires a completely secured network to avoid unauthorised and malicious use (Zhang and Nunamaker, 2003). Besides technical compatibility, before selecting an LMS it is also necessary to check whether it confirms various internationally acceptable e-learning standards or not e.g. Sharable Content Object Reference Model (SCORM) (Sanchez-Alonso \& Frosch-Wilke, 2005).

$\checkmark$ DESIGN SPECIFICATIONS OF AN LMS: The two above mentioned factors are crucial in selecting an LMS \& considered as organizational factors. Besides, the design specifications include functionality \& pedagogical style also increases the acceptance rate in LMS selection. Some of the important aspects of the design specification of an LMS are,

- Clear and User Friendly Graphical Interface

- Well Designed Course Repository

- Course Administration Capability

- Capability of Interaction among the Users of LMS

- Evaluation and Feedback

- Student's Profile

$\checkmark \quad$ LMS PEDAGOGY: The most significant component of an LMS is its endorsed pedagogical styles. Comparing and evaluating LMS based on feature-richness alone would be unjustifiable. The constructivist methodology is one of the preferred pedagogical methods for online learning. Online learning platforms in an LMS are well suited for promoting and engaging students in dialogue with both teachers and students, supporting the initiative and autonomy of students, and providing immediate feedback on them (Jonassen et. al, 1999). For this reason, the constructivist methodology is well suited with the online learning platforms. In this approach, students develop their knowledge by applying their current knowledge to new situations and thus learn new things. Carmean and Haefner (2002) came up with a core collection of deeper learning concepts after analysing the work of the various educators. They believe that "deeper learning" or engaging learning leads to a better understanding of concepts when learning is social, interactive, meaningful, stimulating, and owned by the students. These five principles are discussed concerning LMS in the table 1 given below:

\begin{tabular}{|c|c|c|}
\hline Learning is & When... & $\begin{array}{c}\text { Accomplished these } \\
\text { targets in an LMS } \\
\text { environment }\end{array}$ \\
\hline Social & $\bullet \begin{array}{c}\text { it facilitates } \\
\text { interaction } \\
\text { between students } \\
\text { themselves, } \\
\text { between students }\end{array}$ & $\begin{array}{c}\text { by virtual chat, } \\
\text { discussion boards, } \\
\text { announcement } \\
\text { postings. }\end{array}$ \\
\hline
\end{tabular}

\begin{tabular}{|c|c|c|}
\hline & $\begin{array}{c}\& \text { faculty } \\
\text { members and } \\
\text { with parents as } \\
\text { well. }\end{array}$ & \\
\hline Interactive & $\begin{array}{l}\text { the practice and } \\
\text { reinforcement are } \\
\text { emphasized. } \\
\text { involvement in } \\
\text { real-world tasks is } \\
\text { emphasized. }\end{array}$ & $\begin{array}{l}\bullet \quad \text { by using } \\
\text { interactive evaluation } \\
\text { modules to analyse } \\
\text { the responses and } \\
\text { provide immediate } \\
\text { feedback to the } \\
\text { students. }\end{array}$ \\
\hline Meaningful & $\begin{array}{l}\text { - new knowledge } \\
\text { is integrated into } \\
\text { the learner's } \\
\text { world. } \\
\text { new knowledge } \\
\text { is demonstrated to } \\
\text { the student. }\end{array}$ & $\begin{array}{l}\text { - } \quad \text { by provided } \\
\text { students with the } \\
\text { additional } \\
\text { information after } \\
\text { carefully use of } \\
\text { appropriate website } \\
\text { hyperlinks. } \\
\text { by involving } \\
\text { students to design } \\
\text { new knowledge } \\
\text { presentations and to } \\
\text { share such } \\
\text { presentations with } \\
\text { other students and } \\
\text { subject teachers.. }\end{array}$ \\
\hline Stimulating & $\begin{array}{c}\text { it respects } \\
\text { diverse talents } \\
\text { and ways of } \\
\text { learning. } \\
\text { it is done in } \\
\text { high-challenge, } \\
\text { low-threat } \\
\text { environments. }\end{array}$ & $\begin{array}{l}\bullet \quad \text { by using } \\
\text { audio/visual tools, \& } \\
\text { multimedia. } \\
\text { by using of } \\
\text { Synchronous as well } \\
\text { as asynchronous } \\
\text { learning tools. }\end{array}$ \\
\hline $\begin{array}{l}\text { Student- } \\
\text { owned }\end{array}$ & $\begin{array}{c}\text { - it promotes } \\
\text { self-learning i.e. } \\
\text { students take care } \\
\text { of their own } \\
\text { learning, note } \\
\text { mistakes, prepare } \\
\text { ahead, allocate } \\
\text { class time and } \\
\text { memory to assign } \\
\text { tasks. } \\
\text { it emphasizes } \\
\text { learner } \\
\text { independence and } \\
\text { choice. }\end{array}$ & $\begin{array}{l}\text { by enhancing } \\
\text { students' ability to } \\
\text { seek answers quickly. }\end{array}$ \\
\hline
\end{tabular}

Table 1: Deeper Learning Principles in LMS perspective (adapted from Carmean and Haefner, 2002)

\section{LMS DEPLOYMENT OPTIONS}

$\checkmark$ CLOUD-BASED (SAAS): In these cloud-hosted LMS platforms, both the system and any software enhancements or improvements are carried out \& maintained by LMS vendors. The end-user interface only requires the allocated user name $\&$ password of the learner to use the LMS platform. No software installation is compulsory, benefits those organizations need a quick start-up.

$\checkmark$ SELF-HOSTED: These LMS platforms require software installation by direct download from the vendor's website or by burning physical software discs. However, the 
former is more popular in these days. This type of LMS enables greater creative control \& customization in the user end but also lacks in terms of support \& pricing model, e.g. users additionally need to pay for new updates, customer support \& IT know-how.

$\checkmark$ DESKTOP APPLICATION: In this case, LMS is installed as a desktop application with enabling multiple device accessibility and make it more collaborative \& userfriendly.

$\checkmark$ MOBILE APPLICATION: This type of LMS facilitates users to access the e-learning platform whenever \& wherever. It also helps educators to upload online training content \& course material and enables tracking facility for the learners with automatic notification \& feedback option.

\section{E. LMS CUSTOMER TYPES}

(i) Large Enterprises: Large organizations e.g. a university consists of hundreds or thousands of learners, faculty members, and other staff members. Using an LMS facilitates monitoring \& controlling of the activity of each member of the institution. With the help of these LMS, universities can also introduce distance learning programme $\&$ online training initiatives from around the world.

(ii) Small \& Medium Businesses (SMBs): Small and Medium-sized Businesses (SMBs) get benefited from this type of LMS as less human resources involved in these type of organizations. The LMS tools also scale up together with the organization to fit the ever-changing training needs of users.

(iii) Freelancers: LMS platforms built for eLearning freelancers work with several users and need to produce a diverse variety of outcomes. These LMS can feature integrated collaborative tools that allow users to fly solo or work with a remote eLearning team.

\section{F. LMS LICENSING TYPES}

$\checkmark$ OPEN SOURCE: Open Source LMS is typically free, and web-based where users can change the source code according to their needs. Besides, several open-source solutions have active online communities that facilitate users by providing feedback, technical know-how \& help with troubleshooting if they encounter any problem. The downside is users usually need some degree of expertise in programming.

$\checkmark$ FREE LICENSE: There are several free LMS options, usually open-source systems. However, the money that users save on licensing or monthly fees may be spent on IT staff, especially if they don't have any programming experience. In addition, users may have to deal with a steep learning curve to get the best out of the learning management system.

$\checkmark \quad$ PAID LICENSE: Paid LMS require a monthly or annual fee. Some even allow users to purchase the software outright. They typically offer more advanced support options and user-friendly features.

\section{G. LMS PRICING MODELS}

(i) Licensing: This LMS pricing scheme includes a licence fee, rather than paying per user. Usually, an annual fee that an organization must renew on an annual basis, or an outright upfront charge that grants unlimited lifetime access. However, as technology advances organizations probably still have to purchase replacement software in the near future.

(ii) Subscription: Typically a subscription fee permits users to access to all LMS functionality or relies on a pay-peruse model. This pricing model involves a fee for each active user or device. The LMS vendor offers various price ranges according to situations. This is a perfect approach for smaller companies looking to reduce the costs of online training while also having to be able to scale up the learning management system as their organization grows.

(iii) Freemium: These LMS platforms are free for basic functionality, but more advanced functionalities such as addons or enhancements are subject to a fee. For example, a more robust eLearning assessment system, or advanced reports.

\section{H. LMS SPECIFICATION SUPPORT TYPES}

(i) SCORM 2004: This set of standards helps eLearning authoring tools and eLearning content communicate with the Learning Management System. SCORM 2004 enables tools to format eLearning content in such a way that's shareable across the board.

(ii) Tin Can API: Also known as Experience API, Tin Can spec support is often viewed as the follow-up to SCORM. It allows for external learning activities and tracking, and gives eLearning pros the ability to develop and deploy native mobile apps.

(iii) AICC: Aviation Industry CBT Committee support allows the LMS and eLearning content to communicate via HAC protocols. In essence, the system relies on an HTML form to transmit the information, then the LMS relays the information back via text.

(iv) IMS LTI: The IMS Global Learning Consortium has implemented learning tools interoperability (LTI), specializes in remote-hosted applications (apps) and web-based eLearning content.

\section{ADVANTAGES OF LMS}

Learning platforms allow effective, complete, overall control of the administration, automation, communication with users, teachers and trainers, and of course content management. Since the study of the effectiveness of LMS is the primary goal of this paper, some main advantages of LMS from the students' as well as teachers' point of view are summarized below:

\begin{tabular}{|c|c|c|}
\hline SN & Advantages for Students & $\begin{array}{c}\text { Advantages for } \\
\text { Teachers }\end{array}$ \\
\hline 1 & $\begin{array}{c}\text { Single spot availability of } \\
\text { all course related } \\
\text { information. }\end{array}$ & $\begin{array}{c}\text { Convenience in } \\
\text { providing additional } \\
\text { resources to students } \\
\text { besides class lectures. }\end{array}$ \\
\hline 2 & $\begin{array}{c}\text { Easy access to } \\
\text { information - anywhere, } \\
\text { anytime. }\end{array}$ & $\begin{array}{c}\text { Access to students } \\
\text { other than class } \\
\text { timings. }\end{array}$ \\
\hline 3 & Convenience in keeping & Timely feedback can \\
\hline
\end{tabular}




\begin{tabular}{|c|c|c|}
\hline \multirow{4}{*}{4} & $\begin{array}{c}\text { track of progress in a } \\
\text { course. }\end{array}$ & $\begin{array}{c}\text { be provided to students } \\
\text { on their progress in a } \\
\text { particular course. }\end{array}$ \\
\hline \multirow{5}{*}{5} & $\begin{array}{c}\text { Availability of practice } \\
\text { questions and suggested } \\
\text { solutions make learning } \\
\text { more engaging and } \\
\text { practical. }\end{array}$ & $\begin{array}{c}\text { Better monitoring of } \\
\text { students is possible as } \\
\text { it is easy to keep track } \\
\text { of all assignments - } \\
\text { submitted as well as } \\
\text { not submitted. }\end{array}$ \\
& $\begin{array}{c}\text { Ease of arranging off } \\
\text { campus meetings with } \\
\text { instructor and class mates } \\
\text { in a virtual environment. }\end{array}$ & $\begin{array}{c}\text { It offers a good } \\
\text { platform for using } \\
\text { innovative ideas in } \\
\text { teaching. }\end{array}$ \\
\hline
\end{tabular}

Table 2: Advantages of an LMS (adapted from Iqbal \& Qureshi, 2011)

\section{LEARNING MANAGEMENT SYSTEM (LMS): PRACTICAL IMPLEMENTATION}

The practical part of the study consisting of explaining detailed technological aspects of implementation of one of the most famous LMS, "Blackboard" in Chandigarh University. The university has adopted the blended teaching learning model through shifting its pedagogy and course creation on Blackboard LMS. Being a University offering 150+ courses in various programs, every program has its own unique teaching pedagogy, learning process and assessment practices.

Blackboard is one of the leading commercial LMS products used in a large organization and is the most widely-adopted learning management system. It is a virtual hub for student services that provide access to online course materials, grades, organizations, accounts, and many other academic and campus services. Blackboard provides a password-protected environment and has administration tools that make teaching online easier.

Recently, researchers have compared learning management systems based on their functionality, userfriendliness, and cost. Some of the key features evaluated in a learning management system are its usability, availability, security, stability, interoperability, and scalability. This part of the study explores the effectiveness of such features on account of implementing "Blackboard" LMS in Chandigarh University.

\section{A. SIGN IN TO BLACKBOARD}

The first step is to "Create an Account" on the Blackboard with authorised e-mail id (institutional mail) which needs to be approved before continuing in https://blackboard.coursesites. com. As Chandigarh University purchase blackboard it is now integrated with the Chandigarh University Integrated Management System (CUIMS) and any faculty of Chandigarh University needs to $\log$ in through https://cuchd.blackboard.com with employee code as user name and password set as same for CUIMS.

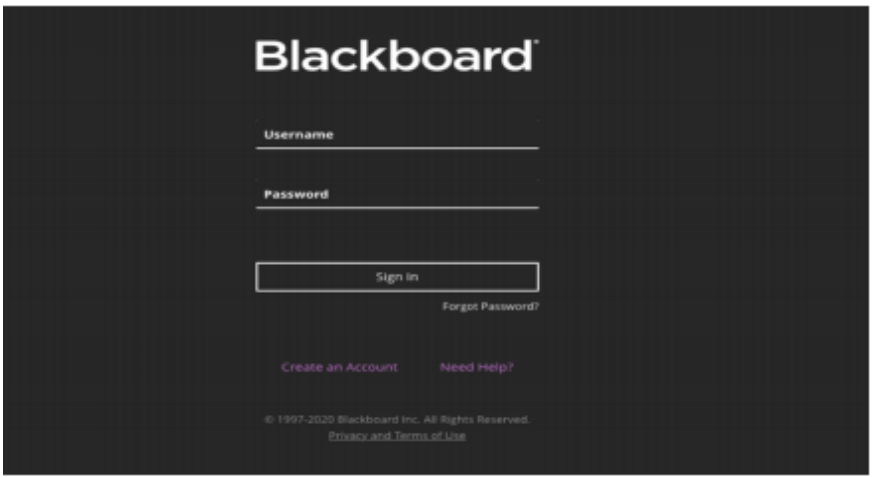

Figure 2: Sign in Option in Blackboard

\section{B. COURSE AND CONTENT CREATION}

After $\log$ in the next screen will be dashboard screen which contains various options available. To create a course the courses option needs to be clicked in this. Courses in blackboard represent the subject which a faculty member needs to teach. Faculty will have to create individual courses for all the different subjects and in each course various types of contents he/she is going to teach. The step by step guide for creation courses and contents are summarized in following points,

$\checkmark$ The screen of "CourseSites by Blackboard" will be dedicated screen for the courses. There are ten courses available to each faculty in the platform out of which it has 5 original courses and 5 ultra-courses. The 5 original courses can also be converted to 5 ultra-courses. The course style chosen by Chandigarh University to be followed is Ultra courses. Hence, each faculty is to supposed to choose Ultra courses only.

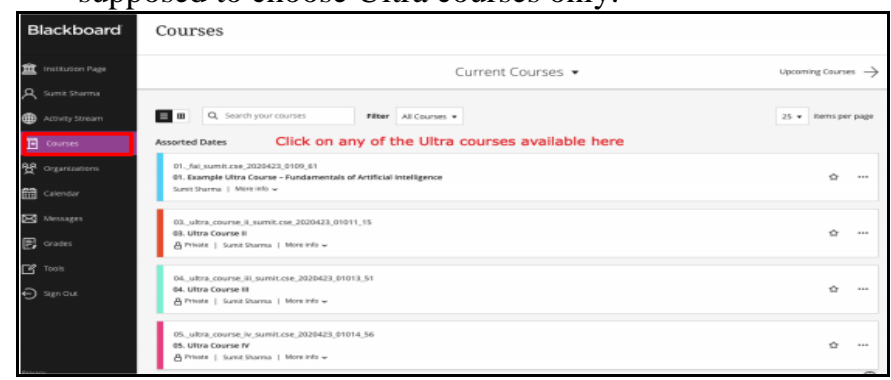

Figure 3: Creation of a New Course

$\checkmark$ After clicking any of the course, the individual course screen will show up (figure 3). The first step to be followed here would be to change the course name to the subject name as per the scheme of the university.

$\checkmark$ The next step would be to start uploading the course content for the course subject. The plus sign in the course homepage needs to be clicked, which will display set of various options to create content for the course (figure 4). The functionality of each option is being explained below:

- CREATE: This option is to be selected if the faculty wants to create either documents, links, folders, discussions, assignments, and tests.

- COPY CONTENT: This option is to be selected if the faculty wants to copy the contents from an existing course, he/she is teaching or if the faculty wants to completely copy an existing original course into the Ultra Course. 
- UPLOAD: This option is to be used if the faculty straight away wants to upload the material from his/her personal computer in the course. The file types supported are: DOC, DOCX, HTM, HTML, MP3, MPG, PDF, PPT, PPTX, XLS, XLSX, RTF, TXT, ZIP, and most image types.

- CONTENT MARKET: This option is to add the existing learning materials already available on blackboard via its partnerships with content providers. The availability of this feature is based upon the administrator privileges bought in the package.

- CLOUD STORAGE: This option helps faculty to copy content from web apps like MyDrive, Google Drive, Dropbox etc. The faculty needs to login into desired web app and then can select files from his/her drive which needs to be added in the course.

- CONTENT COLLECTION: The content collection is shared space of the complete institutions shared repositories. The content can be found in any of the following levels i.e. personal, course and institution folder.

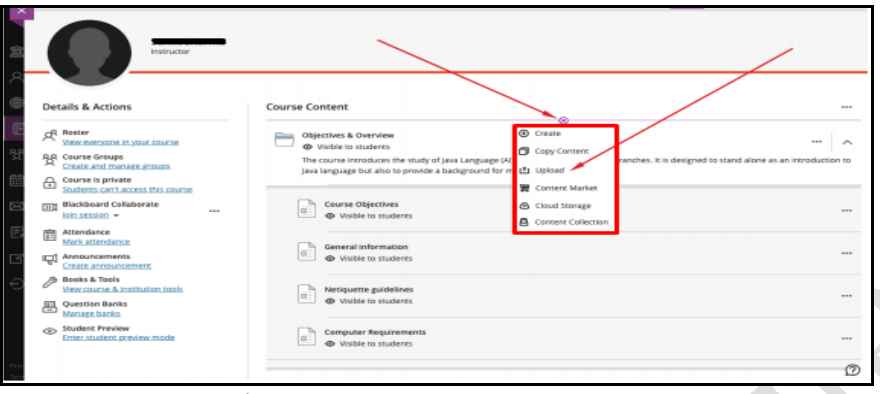

Figure 4: Options to Create Course Content

\section{ENROLL STUDENTS IN THE COURSE}

After all the content of the course has been created. Faculty has to make sure that all the students of his/her section has enrolled in the course. The steps to be followed for enrolling in the course as follows:

$\checkmark$ Click on Roster in left navigation drawer as shown below (figure 5).

$\checkmark \quad$ The next step will be to click the plus sign in the top right corner as shown in the figure 6 below.

$\checkmark \quad$ The next screen will have two options to enrol students in the course. First option is to type the email addresses of all the students in the textbox shown in the figure 7 below.

$\checkmark \quad$ In the same screen (figure 8), there is another option to add the students in the course i.e. via a shareable link. Faculty needs to scroll down and the link can be found which can be shared by any possible means.

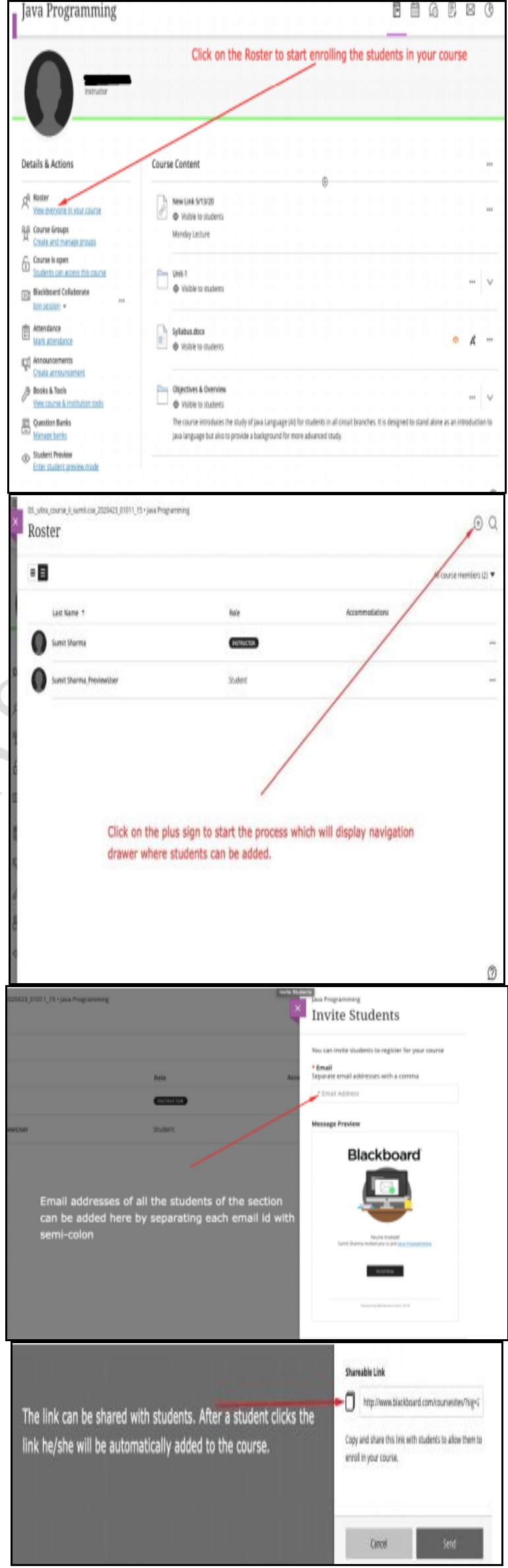

Figure 5-8: Student Enrollment in a Particular Course 
In this module there are also option to "create sections", “ message to individual student or group of students", "give accommodation to students in a particular course", "create \& view analytics of assignments \& tests" etc.

\section{ATTENDANCE MARKING}

Attendance of students of a particular session can be marked automatically and can be export as a downloadable excel sheet. The following steps should be followed for download attendance from Blackboard,

$\checkmark$ Go to Blackboard Collaborate dropdown with three dots(figure 9)

$\checkmark$ Go to View Room Reports

$\checkmark \quad$ Go to Step 1 shown in the figure 10(where user can open all session options) and go to Step 2 shown in the figure 10 (View Reports) to download the report in CSV format.

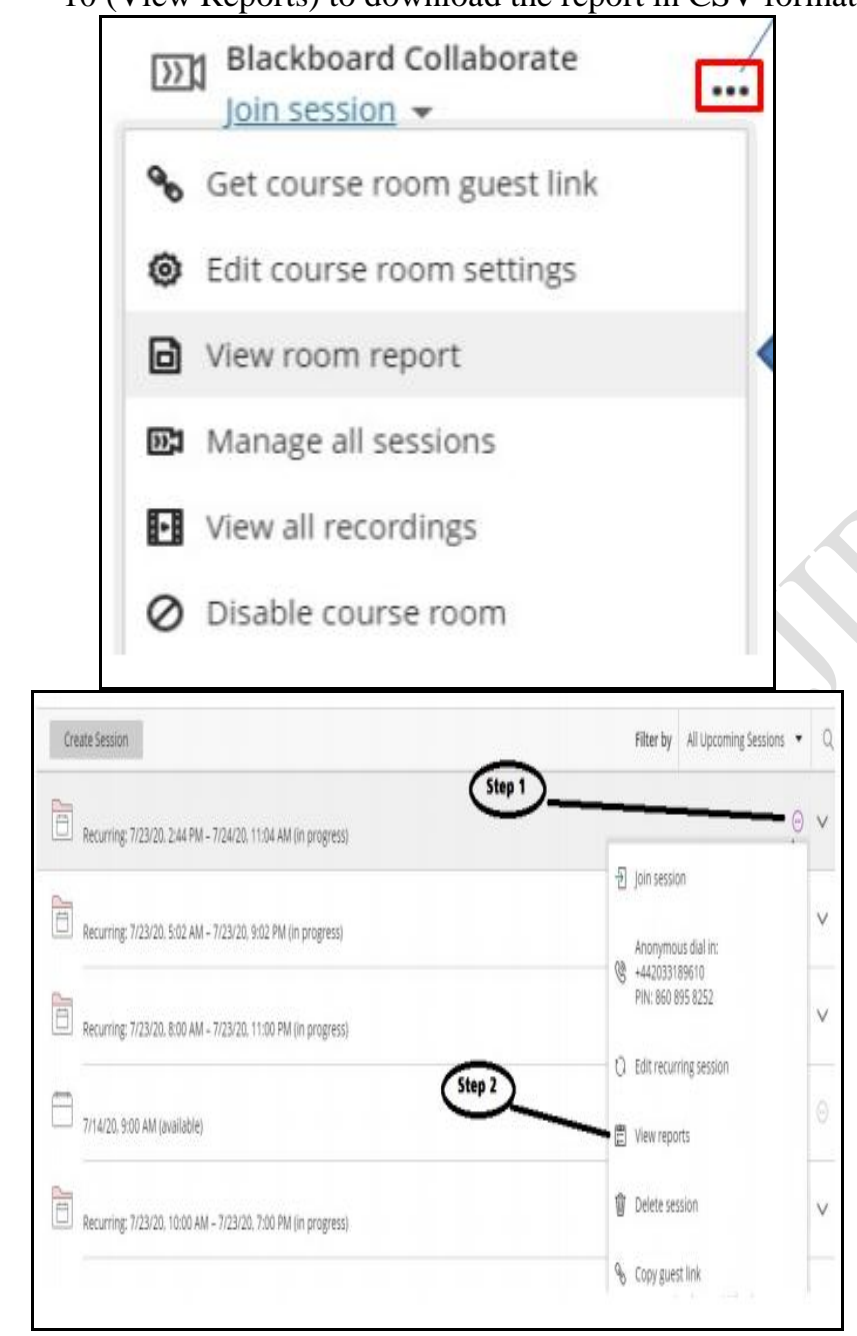

Figure 9-10: Attendance Marking on Blackboard Collaborate

\section{E. ASSESSMENT CONTROL MODULE}

Assessment control module provide deep insights to understand the various controls and checks to be set up in designing and launching any assessment task (either graded or non-graded) in theory and practical courses on Blackboard. The controls have been fixed as per the guidelines mentioned in the Assessment Model Manual for both theory and practical courses available on Blackboard Sample Course Shell.

Assessment control module controls the procedure of assign "Assignments" or "Homework", take instant "Quiz" or "Test" and arrange "Discuss Forum" for the students. In CUIMS of Chandigarh University to assign assignments for students following quick steps and guides should be followed,

$\checkmark$ On course content page first click (+) button in the destination where assessment is required to be created. A popup will open and then click on create.

$\checkmark \quad$ From create item option check for assessments and click on to assignment tab (figure 11).

$\checkmark$ On landing page of assignments following controls/options can be seen. The settings icon needs to be clicked to access controls/settings, same is mentioned as item number 8 in figure 12 below.

$\checkmark$ There are also many set up of controls for assignment which may be used by the educator to specify the assignment types and requirements from the learner, e.g. Due Date, Grade Category, Attempts Allowed, Maximum Points, Evaluation Options, Time Limit, grading Rubric etc.

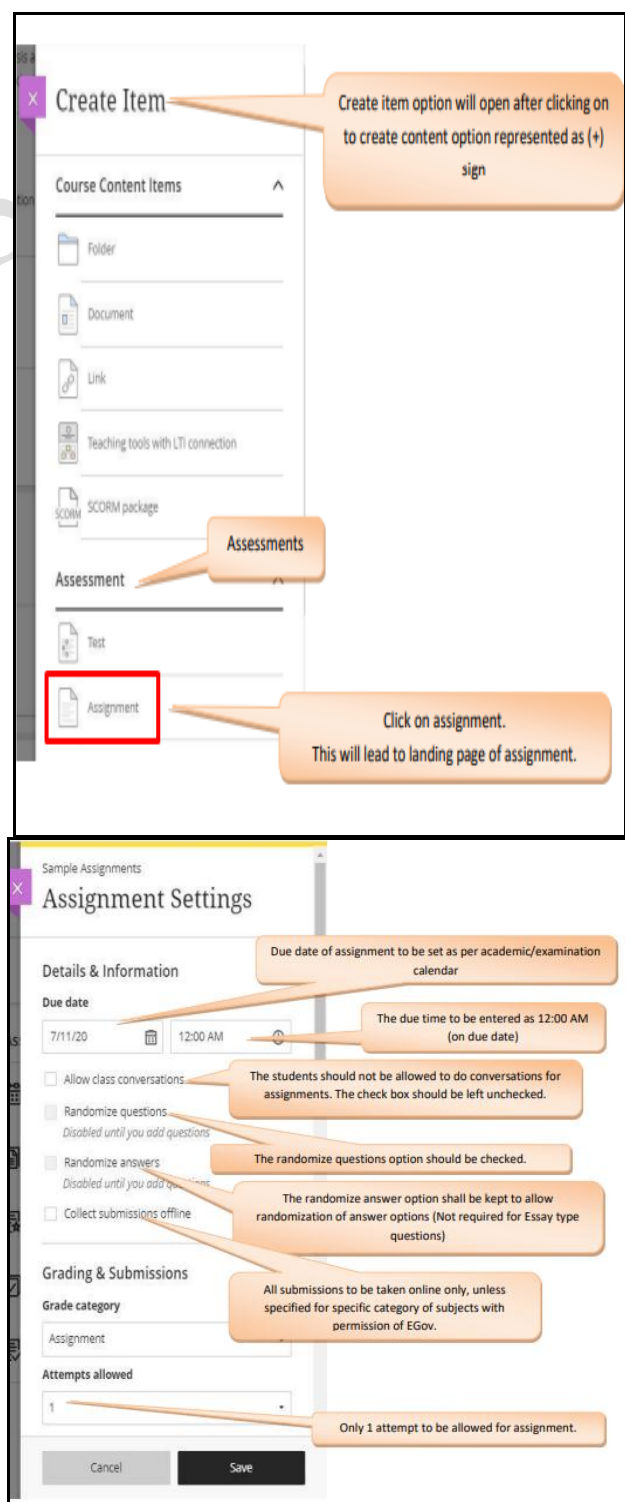

Figure 11-12: Assign Assignments in Blackboard LMS 
Blackboard also enable the feature of taking an instant quiz in its online platform. It can help in taking an internal assessment or end-semester exam in some distance mode courses. The steps are the same as assigning assignments or homework. Hereafter check for assignment option in create item tab click on to "test tab" rather than "assignment tab" (figure 13). On the landing page, there are same control options as of assigning assignments or homework.

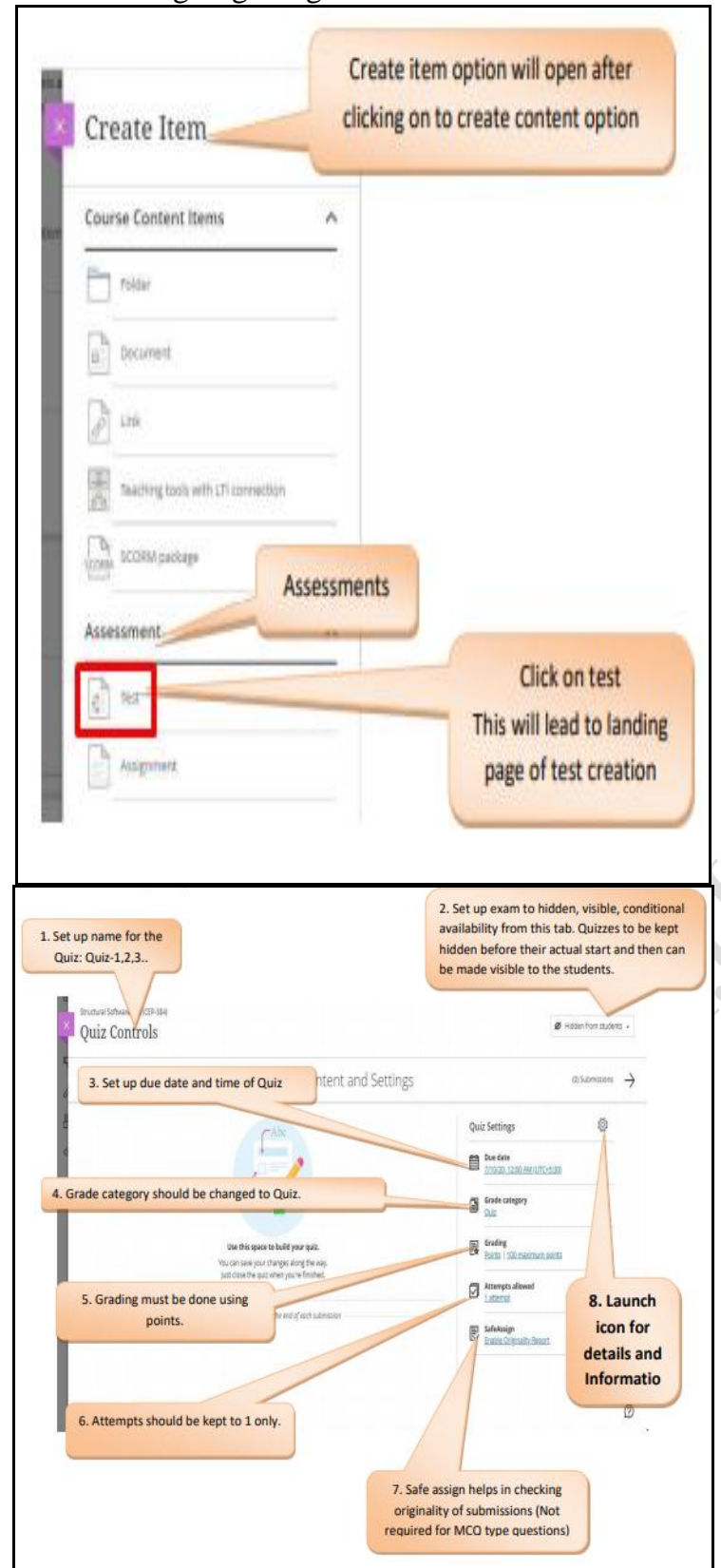

Figure 13-14: Assign Quiz in Blackboard LMS

To present an online presentation the path is equal of assigning assignments or homework. The end semester test can also be taken by adopting the same procedure as of taking a quiz on Blackboard LMS.

For arrange a "Discussion Forum" From create item option check for participation \& engagement and click on discussion tab (figure 15). On landing page of discussion forum following controls/options can be seen (figure 16). The settings icon needs to be clicked to access controls/settings, same is mentioned as item number 4 in figure 16 below.

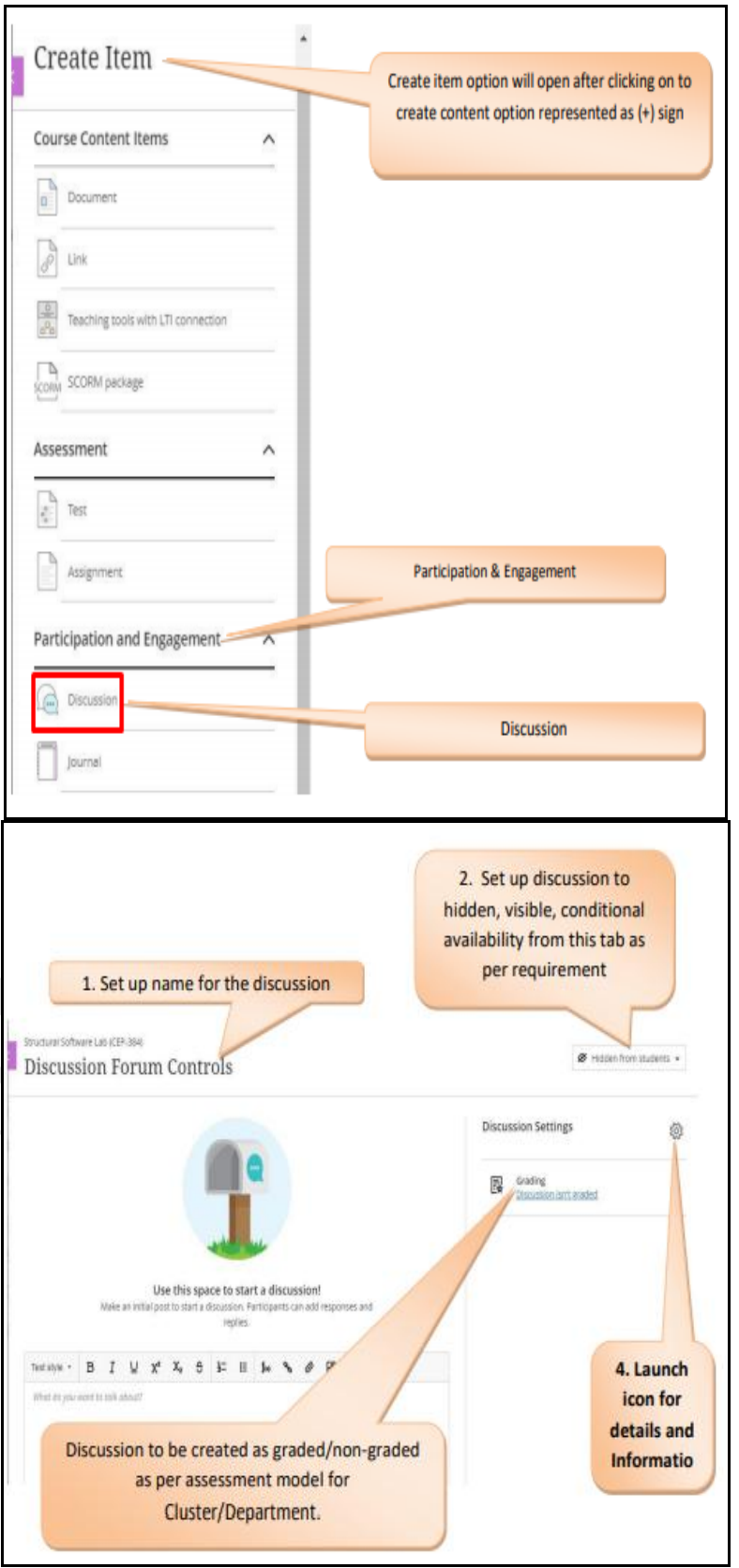

Figure 15-16: Arrange Discuss Forum in Blackboard LMS

\section{F. CLASSROOM ENGAGEMENT}

There are opportunities in BB Collaborate to engage students in the online mode of learning while attending the theory and practical classes. Student engagement analysis ensures that whether the students are sincere in online lectures or not. Chandigarh University specified 4 modes of engagements for students while attending lectures in Blackboard LMS. 


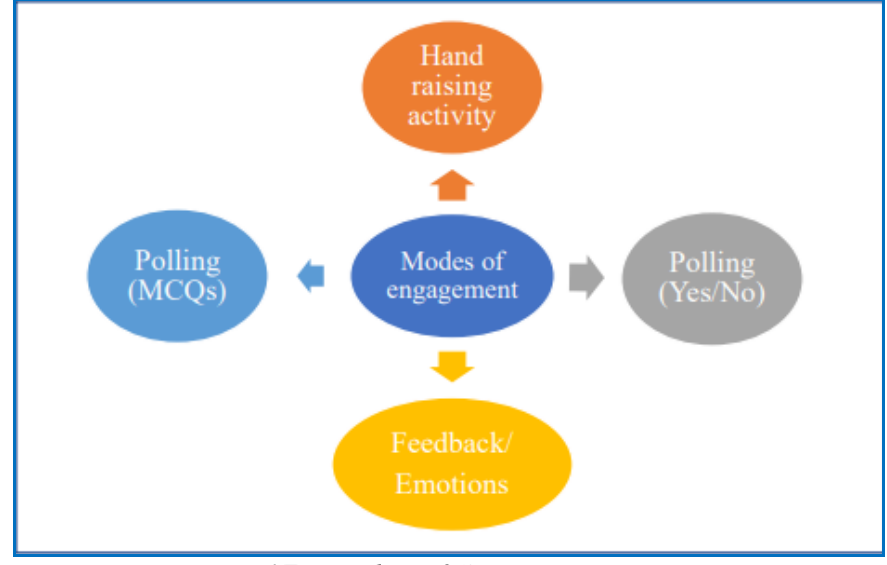

Figure 17: Modes of Session Engagement

\section{COMPARISON BETWEEN BLACKBOARD AND OTHER COMMON LMS}

Following table 3 displays in detail comparison of Blackboard, Canvas \& Moodle LMS considering general overview, features, pricing etc. as a parameter;

\begin{tabular}{|c|c|c|c|}
\hline & Blackboard & Canvas & Moodle \\
\hline \multicolumn{4}{|l|}{ 1. Overview } \\
\hline a) Customers & $\begin{array}{l}\text { - Large } \\
\text { Enterprises } \\
(>10,000) \\
\text { - Universities } \\
\text { - Public } \\
\text { Administrations } \\
\text { - Small/Medium } \\
\text { Businesses }\end{array}$ & $\begin{array}{l}\text { - } \text { Public } \\
\text { Administrations } \\
\text { - Small/Medium } \\
\text { Businesses }\end{array}$ & $\begin{array}{l}\text { - } \text { Academic } \\
\text { - Freelancers } \\
\text { - Non Profits } \\
\text { - Public } \\
\text { Administrat } \\
\text { ions }\end{array}$ \\
\hline b) Deployment & $\begin{array}{l}\text { - Desktop } \\
\text { Application } \\
\text { - Mobile } \\
\text { Application } \\
\text { - Self-Hosted } \\
\text { System } \\
\text { - Software as a } \\
\text { Service / Cloud }\end{array}$ & $\begin{array}{l}\text { - } \text { Mobile } \\
\text { Application } \\
\text { - Software as a } \\
\text { Service / Cloud }\end{array}$ & $\begin{array}{l}\text { - Mobile } \\
\text { Application } \\
\text { - Self-Hosted } \\
\text { Cloud- } \\
\text { based } \\
\text { - Self-Hosted } \\
\text { System }\end{array}$ \\
\hline c) Platforms & $\begin{array}{l}\text { - Linux } \\
\text { - Mac } \\
\text { - Windows }\end{array}$ & $\begin{array}{l}\text { - Linux } \\
\text { - Mac } \\
\text { - Windows }\end{array}$ & $\begin{array}{l}\text { - Linux } \\
\text { - Mac } \\
\text { - Windows }\end{array}$ \\
\hline d) Browsers & $\begin{array}{l}\text { - Apple Safari } \\
\text { - Google Chrome } \\
\text { - Internet } \\
\text { Explorer } \\
\text { - Mozilla Firefox }\end{array}$ & $\begin{array}{l}\text { - Apple Safari } \\
\text { - Google Chrome } \\
\text { - Internet } \\
\text { Explorer } \\
\text { - Mozilla Firefox }\end{array}$ & $\begin{array}{ll}\text { - Apple } \\
\text { Safari } \\
\text { - Google } \\
\text { Chrome } \\
\text { - Internet } \\
\text { Explorer } \\
\text { - Mozilla } \\
\text { Firefox }\end{array}$ \\
\hline e) Training & $\begin{array}{l}\text { - Documentation } \\
\text { - In Person } \\
\text { - Live Online } \\
\text { - Webinars }\end{array}$ & $\begin{array}{l}\text { - Documentation } \\
\text { - In Person } \\
\text { - Live Online } \\
\text { - Online } \\
\text { Tutorials } \\
\text { - Webinars } \\
\end{array}$ & $\begin{array}{l}\text { - Documentat } \\
\text { ion } \\
\text { - Online } \\
\text { Tutorials }\end{array}$ \\
\hline f) Support & $\begin{array}{l}\text { - } 24 / 7 \\
\text { - Business Hours } \\
\text { - Live Online }\end{array}$ & $\begin{array}{l}\text { - } 24 / 7 \\
\text { - Business Hours } \\
\text { - Live Online } \\
\text { - Phone }\end{array}$ & $\begin{array}{l}\text { - FAQ } \\
\text { - Online } \\
\text { Community }\end{array}$ \\
\hline $\begin{array}{l}\text { g) Supported } \\
\text { Specification } \\
\text { S }\end{array}$ & $\begin{array}{ll}\text { - } & \text { AICC } \\
\text { - } & \text { IMS LTI } \\
\text { - } & \text { SCORM } 1.2 \\
\text { - } & \text { SCORM } 2004 \\
\text { - } & \text { xAPI/Tin Can } \\
& \text { API }\end{array}$ & $\begin{array}{ll}- & \text { IMS LTI } \\
- & \text { SCORM } 2004 \\
- & \text { xAPI/Tin Can } \\
& \text { API }\end{array}$ & $\begin{array}{ll}\text { - } & \text { AICC } \\
\text { - } & \text { IMS LTI } \\
\text { - } & \text { SCORM } \\
& 1.2 \\
\text { - } & \text { SCORM } \\
& 2004 \\
\text { - } & \text { xAPI/Tin }\end{array}$ \\
\hline
\end{tabular}

\begin{tabular}{|c|c|c|c|}
\hline & & & Can API \\
\hline \multicolumn{4}{|l|}{ 2. Features } \\
\hline $\begin{array}{l}\text { a) User } \\
\text { Accounts }\end{array}$ & - Add a new user & $\begin{array}{l}\text { - Add a new user } \\
\text { - Browse list of } \\
\text { user } \\
\text { - Bulk user } \\
\text { actions } \\
\text { - Upload users }\end{array}$ & $\begin{array}{l}\text { - Not } \\
\text { available }\end{array}$ \\
\hline $\begin{array}{l}\text { b) Activity } \\
\text { Grading }\end{array}$ & - Gradebook & - Gradebook & $\begin{array}{l}\text { - } \text { Course } \\
\text { History } \\
\text { - Gradebook } \\
\text { - Gradebook } \\
\text { audit trail } \\
\text { - Gradebook } \\
\text { comments } \\
\text { - Manual } \\
\text { Grading } \\
\text { ("Marking") } \\
\text { - Multiple } \\
\text { grading } \\
\text { scales }\end{array}$ \\
\hline $\begin{array}{l}\text { c) User } \\
\text { Authenticati } \\
\text { on }\end{array}$ & $\begin{array}{l}\text { - SAML2/API } \\
\text { Integration } \\
\text { - Self- } \\
\text { Registration }\end{array}$ & $\begin{array}{l}\text { - Self- } \\
\text { Registration }\end{array}$ & $\begin{array}{l}\text { - Manual } \\
\text { Accounts } \\
\text { - Self- } \\
\text { Registration } \\
\text { - Self- } \\
\text { Registration } \\
\text { w. Admin } \\
\text { Confirmatio } \\
\text { n }\end{array}$ \\
\hline $\begin{array}{l}\text { d) Course } \\
\text { Categories }\end{array}$ & $\begin{array}{l}\text { No inbuilt } \\
\text { course } \\
\text { categories } \\
\text { available }\end{array}$ & $\begin{array}{l}\text { No inbuilt } \\
\text { course } \\
\text { categories } \\
\text { available }\end{array}$ & $\begin{array}{l}\text { - Assign } \\
\text { Courses to } \\
\text { categories } \\
\text { - Create new } \\
\text { Categories } \\
\text { - Manage } \\
\text { Categories }\end{array}$ \\
\hline $\begin{array}{l}\text { e) Certificate } \\
\text { Managemen } \\
\text { t }\end{array}$ & $\begin{array}{l}\text { Manage } \\
\text { certification } \\
\text { templates }\end{array}$ & $\begin{array}{l}\text { - Feature not } \\
\text { available }\end{array}$ & $\begin{array}{l}\text { - Feature not } \\
\text { available }\end{array}$ \\
\hline $\begin{array}{l}\text { f) Compliance } \\
\text { Managemen } \\
t\end{array}$ & $\begin{array}{l}\text { Certification } \\
\text { Expiration } \\
\text { Management }\end{array}$ & $\begin{array}{l}\text { - Feature not } \\
\text { available }\end{array}$ & $\begin{array}{l}\text { - Feature not } \\
\text { available }\end{array}$ \\
\hline $\begin{array}{l}\text { g) Course } \\
\text { Creation }\end{array}$ & $\begin{array}{l}\text { - Assignments } \\
\text { Engine } \\
\text { - Built-In } \\
\text { Authoring Tool } \\
\text { - Consume online } \\
\text { video content } \\
\text { - Scheduling } \\
\text { LIVE events } \\
\text { - Tests Engine } \\
\text { - Upload courses }\end{array}$ & $\begin{array}{l}\text { - } \text { Assignments } \\
\text { Engine } \\
\text { - Built-In } \\
\text { Authoring Tool } \\
\text { - Can reuse } \\
\text { PPTs PDFs, } \\
\text { Videos } \\
\text { - Changing } \\
\text { Course default } \\
\text { settings } \\
\text { - Consume online } \\
\text { video content } \\
\text { - Scheduling } \\
\text { LIVE events } \\
\text { - Tests Engine } \\
\text { - Upload courses }\end{array}$ & $\begin{array}{l}\text { - Assignment } \\
\text { s Engine } \\
\text { - Built-In } \\
\text { Authoring } \\
\text { Tool } \\
\text { - Changing } \\
\text { Course } \\
\text { default } \\
\text { settings } \\
\text { - Course } \\
\text { backup } \\
\text { Options } \\
\text { - Survey } \\
\text { Engine } \\
\text { - Tests } \\
\text { Engine } \\
\text { - Upload } \\
\text { courses }\end{array}$ \\
\hline $\begin{array}{l}\text { h) Customizati } \\
\text { on }\end{array}$ & $\begin{array}{l}\text { - Personalized } \\
\text { views }\end{array}$ & $\begin{array}{ll}\text { - } \begin{array}{l}\text { Feature } \\
\text { available }\end{array} & \text { not }\end{array}$ & $\begin{array}{l}\text { Personalize } \\
\mathrm{d} \text { views }\end{array}$ \\
\hline $\begin{array}{l}\text { i) User } \\
\text { Enrollment }\end{array}$ & $\begin{array}{l}\text { - Attendance } \\
\text { Tracking } \\
\text { - Manual } \\
\text { Enrollment } \\
\text { - Self-enrollment } \\
\text { - Self-enrollment } \\
\text { (with a PIN \#) }\end{array}$ & $\begin{array}{l}\text { - Attendance } \\
\text { Tracking } \\
\text { - Automated } \\
\text { Enrollment } \\
\text { (based on User } \\
\text { data) } \\
\text { - Self-enrollment }\end{array}$ & $\begin{array}{l}\text { - Attendance } \\
\text { Tracking } \\
\text { - Automated } \\
\text { Enrollment } \\
\text { (based on } \\
\text { User data) } \\
\text { - Guest } \\
\text { Access } \\
\text { Settings } \\
\text { - Manual } \\
\text { Enrollment } \\
\text { - Self- }\end{array}$ \\
\hline
\end{tabular}




\begin{tabular}{|c|c|c|c|}
\hline & & & \\
\hline $\begin{array}{l}\text { j) Course } \\
\text { Format }\end{array}$ & $\begin{array}{l}\text { - } \text { Course } \\
\text { Discussions } \\
\text { - LIVE Chat } \\
\text { Option } \\
\text { - LIVE } \\
\text { Videoconferenc } \\
\text { ing / Webinar } \\
\text { - Social Format }\end{array}$ & $\begin{array}{l}\text { - } \text { Course } \\
\text { Discussions } \\
\text { - Learner Upload } \\
\text { - LIVE Chat } \\
\text { Option } \\
\text { - LIVE } \\
\text { Videoconferenc } \\
\text { ing / Webinar } \\
\text { - Weekly Format }\end{array}$ & $\begin{array}{l}\text { - } \text { Course } \\
\text { Discussions } \\
\text { - Learner } \\
\text { Upload } \\
\text { - Social } \\
\text { Format } \\
\text { - Topics } \\
\text { Format } \\
\text { - Weekly } \\
\text { Format }\end{array}$ \\
\hline $\begin{array}{l}\text { k) Supported } \\
\text { Learning } \\
\text { Types }\end{array}$ & $\begin{array}{l}\text { - Asynchronous } \\
\text { Instructor-led } \\
\text { - Asynchronous } \\
\text { Self-paced } \\
\text { Blended } \\
\text { Learning } \\
\text { - Synchronous } \\
\text { Virtual } \\
\text { Classroom }\end{array}$ & $\begin{array}{l}\text { - Asynchronous } \\
\text { Self-paced } \\
\text { - Synchronous } \\
\text { Virtual } \\
\text { Classroom }\end{array}$ & $\begin{array}{l}\text { - Asynchrono } \\
\text { us } \\
\text { Instructor- } \\
\text { led } \\
\text { - Asynchrono } \\
\text { us Self- } \\
\text { paced } \\
\text { - Blended } \\
\text { Learning }\end{array}$ \\
\hline $\begin{array}{l}\text { l) Mobile } \\
\text { Learning } \\
\text { Support }\end{array}$ & $\begin{array}{l}\text { - Online (Internet } \\
\text { connected) }\end{array}$ & $\begin{array}{l}\text { - Online (Internet } \\
\text { connected) }\end{array}$ & $\begin{array}{l}\text { Online } \\
\text { (Internet } \\
\text { connected) }\end{array}$ \\
\hline m) Offline & $\begin{array}{ll}\begin{array}{l}\text { Feature } \\
\text { available }\end{array} & \text { not } \\
\end{array}$ & $\begin{array}{ll}\begin{array}{l}\text { Feature } \\
\text { available }\end{array} & \text { not } \\
\end{array}$ & $\begin{array}{l}\text { - Feature not } \\
\text { available }\end{array}$ \\
\hline n) Reports & $\begin{array}{l}\text { - Automated } \\
\text { Report } \\
\text { Scheduling } \\
\text { - Dashboards and } \\
\text { Graphic Reports } \\
\text { - Grading Report } \\
\text { Settings }\end{array}$ & $\begin{array}{l}\text { - Grading Report } \\
\text { Settings }\end{array}$ & $\begin{array}{l}\text { - Email } \\
\text { delivery of } \\
\text { Reports } \\
\text { - Grading } \\
\text { Report } \\
\text { Settings }\end{array}$ \\
\hline \multicolumn{4}{|l|}{ 3. Pricing } \\
\hline $\begin{array}{l}\text { a) Starting } \\
\text { Price }\end{array}$ & - N/A & - N/A & - N/A \\
\hline $\begin{array}{l}\text { b) Pricing } \\
\text { Model }\end{array}$ & - Subscription & $\begin{array}{l}\text { - Free Trial } \\
\text { - Freemium } \\
\text { - Subscription }\end{array}$ & $\begin{array}{l}\text { - Free } \\
\text { - Subscriptio } \\
\mathrm{n}\end{array}$ \\
\hline c) License & - Paid & - Open Source & $\begin{array}{l}\text { - Free } \\
\text { - Open } \\
\text { Source }\end{array}$ \\
\hline d) Free Trial & - No & - Yes & - No \\
\hline
\end{tabular}

Table 3: Comparison between Blackboard, Canvas \& Moodle

As a result of this comparative study, it can be said that among the above three LMS, while Blackboard is subscription-based, it is a stand-alone platform with adequate customer service, secure interface, and preferable for a large organization or institution level.

\section{CONCLUSION}

Neither the usability of Learning Management System (LMS) nor the LMS tool Blackboard is a new area of research. The present study emphasizes briefly about the various types of LMS development options, customer types, licensing types, pricing models, and specification support types also gives a practical approach to the implementation of Blackboard LMS in Chandigarh University for the dry run session from the current semester (August 2020 onwards) for the outbreak of global pandemic COVID-19. Analyzing the basic functionalities of LMS, it can be concluded that LMS is designed to identify training and learning gaps, utilizing analytical data and reporting. LMS is focused on online learning delivery but supports a range of uses, acting as a platform for online content, including courses, both asynchronous based and synchronous based. An LMS may offer classroom management for instructor-led training or a flipped classroom, used in higher education. Again, from the practical approach and the comparative analysis, it can be suggested that Blackboard, as a stand-alone LMS tool help us to fight against the transformation from the conventional to the digital way of learning in a situation of such disaster like the recent outbreak of COVID-19 and suggest that educators and learners must be ready to adopt new changes and requirement of the present situation.

\section{REFERENCES}

[1] Blackboard. (1997). Asia Pacific | Blackboard.com. https://www.blackboard.com/en-apac

[2] Canvas. (2011). Canvas the Learning Management Platform | Instructure. Instructure.Com. https://www.instructure.com/canvas/en-au

[3] Carmean, C., \& Haefner, J. (2002). Mind over Matter Transforming Course Management Systems into Effective Learning Environments. Educase Review, 27-34. shorturl.at/lrCI7

[4] Conley, Q., Earnshaw, Y., \& McWatters, G. (2019). Examining Course Layouts in Blackboard: Using EyeTracking to Evaluate Usability in a Learning Management System. International Journal of Human-Computer Interaction, 36(4), 373-385. https://doi.org/10.1080/10447318.2019.1644841

[5] de Porto Alegre Muniz, M. I., \& de Moraes, A. (2012). Usability issues in Learning Management Systems (LMS). Work, 41, 832-837. https://doi.org/10.3233/wor2012-0250-832

[6] Fuller, D., Rena, F. N., Pearce, K. \& Strand, S. (2000). Internet teaching by style: Profiling the online professor. Educational Technology \& Society, 3(2), 71-85. https://www.ds.unipi.gr/et\&s/journals/3_2/pearce.html

[7] Iqbal, S., \& Qureshi, I. A. (2011). Learning Management Systems (LMS): Inside Matters. Information Management and Business Review, 3(4), 206-216. https://doi.org/10.22610/imbr.v3i4.935

[8] Ismail, J. (2002). The design of an e-learning system: Beyond the hype. The Internet and Higher Education, 4(3-4), 329-336. https://doi.org/10.1016/s1096-7516(01) 00069-0

[9] Jonassen, D. H., Peck, K. L., \& Wilson, B. G. (1999). Learning with technology: a constructivist perspective. Merrill.

[10] Joomla. (2005, August 17). Joomla Content Management System (CMS) - try it for free! Joomla! http://www.joomla.org/

[11] Martin, F. (2008). Blackboard as the Learning Management System of a Computer Literacy Course. MERLOT Journal of Online Learning and Teaching, 4(2), 138-145. https://jolt.merlot.org/vol4no2/martin0608.pdf

[12] Middleton, D. (2010). Putting the Learning into Elearning. European Political Science, 9(1), 5-12. https://doi.org/10.1057/eps.2009.37

[13] Naveh, G., Tubin, D., \& Pliskin, N. (2010). Student LMS use and satisfaction in academic institutions: The organizational perspective. The Internet and Higher 
Education, 13(3), 127-133. https://doi.org/10.1016/ j.iheduc.2010.02.004

[14] Oakes, K. (2002). E-learning: LCMS, LMS — They're not Just Acronyms But Powerful Systems for Learning. Training \& Development, 56(3), 73-75

[15] Panda, S. (2020). A Meta-Analysis of Scholarly Research on Corona virus through Big Data Approach. International Journal of Research in Library Science, 6(2), 66-83. https://doi.org/10.26761/IJRLS.6.2.2020.1339

[16] Parmley, L. (2018, October 7). What is an LMS? (Definition and Examples). Course Method. https://coursemethod.com/lms-definition.html

[17]Rahman, M., Daud, M. Y., \& Ensimau, N. K. (2019). Learning Management System (LMS) in Teaching and Learning. International Journal of Academic Research in Business and Social Sciences, 9(11), 1529-1535. https://doi.org/10.6007/ijarbss/v9-i11/6717

[18] Sánchez-Alonso, S., \& Frosch-Wilke, D. (2005). An ontological representation of learning objects and learning designs as codified knowledge. The Learning Organization, 12(5), 471-479. https://doi.org/10.1108/ 09696470510611410
[19] Sarukhan, A. (2020, August 17). A New Corona virus, a New Epidemic, Many Open Questions. https://www.isglobal.org/en/Corona virus

[20] Selim, H. M. (2007). Critical success factors for elearning acceptance: Confirmatory factor models. Computers \& Education, 49(2), 396-413. https://doi.org/10.1016/j.compedu.2005.09.004

[21] Simonson, M. R., Smaldino, S. E., \& Zvacek, S. (2019). Teaching and learning at a distance: foundations of distance education (7th ed.). Information Age Publishing, Inc.

[22] Tretinjak, M. F. (2018). Moving teaching from blackboard to the learning management system Helping absent students learn from home. 2018 41st International Convention on Information and Communication Technology, Electronics and Microelectronics (MIPRO), 500-502. https://doi.org/ 10.23919/mipro.2018.8400095

[23]Zhang, D., \& Nunamaker, J. F. (2003). Powering ELearning In the New Millennium: An Overview of ELearning and Enabling Technology. Information Systems Frontiers, 5(2), 207-218. https://doi.org/10.1023/a: 1022609809036 